\title{
Gender Issues in Russian Democratization: The Myth or the Reality?
}

\author{
Marina Pilkina \\ Master student of "Political Analysis and Public Policy," National Research University "Higher School of \\ Economics,"Moscow, Russia, pilkina96@gmail.com
}

\begin{abstract}
The aim is to determine whether the descriptive political representation of women is acceptable and achievable for the Russian political reality. Understanding the quality of democracy assumes going beyond mere political participation. It requires the actual representation of traditionally marginalized groups - women. Gender mainstreaming and the involvement of both sexes in political sphere is a sine qua non for any democratic structure. In fact, it may seem that women are included in the democracy, but in practice they are often excluded. Such situation is observed in Russia. The formal female representation in Russian politics exists only to eliminate direct discrimination against women. This nature of women's participation is confirmed by the fact that "women are involved in Russian politics to meet the needs of the regime." The low level of female representation is also linked to the lack of prominent political parties supporting women's rights. Formal female representation does not imply equal gender representation. Balanced representation may require a descriptive political representation - a visible match between the electorate and representatives. If women are half of the population, they should also compose approximately half of the legislative and executive bodies. Given the nature of the gender situation in the Russian political arena, it is not yet possible to represent marginalized groups in a descriptive manner, even though women are about $54 \%$ of the Russian population. The inclusion of women's issues in the agenda and mainstreaming of gender inequality is likely to make the descriptive female representation in Russia achievable.
\end{abstract}

KEYWORDS: women, Russia, democratization, formal and descriptive representation, gender

\section{Is the formal female political representation in Russian politics a coincidence or the only} possible way of development?

When considering the role of women in democracy, theorists usually distinguish between formal, descriptive and substantive representation (Haerpfer 2009, 267). The most achievable is formal, because it requires only the elimination of obstacles to women's participation in politics. Its purpose is the absence of the direct and overt discrimination in politics.

Nowadays there is only a formal representation of women in both legislative and executive branches of authority in the Russian Federation. The current state originates from the period of "perestroika", when the political representation of women has become the only way out of total gender discrimination in political arena. The article mainly analyzes the legislative power, as it reflects the gender order in Russian politics to a greater extent. There are a lot of aspects which defines the current gender order. Here are some of them:

1. Historical component. The transition period from communism to the new Russian regime was fundamentally linked to gender. In the intense era of Mikhail Gorbachev and Boris Yeltsin women faced many problems. On the one hand, the policy of publicity and "perestroika" led to the belated "sexual revolution", which gave some personal freedom to women. On the other hand, the transformation of the Russian state led to a huge national and class inequality. It was accompanied by a change of views on gender issues with the bias in favor of the traditional patriarchal society. Unemployment and poverty rates among women were significantly higher than among men. This situation has led to a decline in the birth rate and a general deterioration of many social institutions.

2. Abolition of the gender quota system and changes in the power structure. Russian gender policy was formed in the context of the abolition of Soviet gender quotas for the representation of women in elected bodies. As a result, the number of women deputies has decreased significantly (Loshakova 2013, 135-136). There are different interpretations of the reasons for the abolition of the gender quotas' system. The departure from quotas occurred when "national parliaments began to play an active role in the management and formation of state policy". Another view is that the 
real integration of women into the political process should have replaced the quota system. In fact, it did not, so now the situation is there, where it should not have been (Aivazova 2017, 7).

In the last 25 years after the collapse of the Soviet Union, there has been a decline in the representation of women in government [Annex 1]. So, in the 11th convocation session of the Supreme Soviet of the USSR (1984-1989) 33\% of the deputies were female. The Congress of People's deputies of the USSR (1989-1991) consisted of 2,249 deputies, $15.7 \%$ of whom were women.

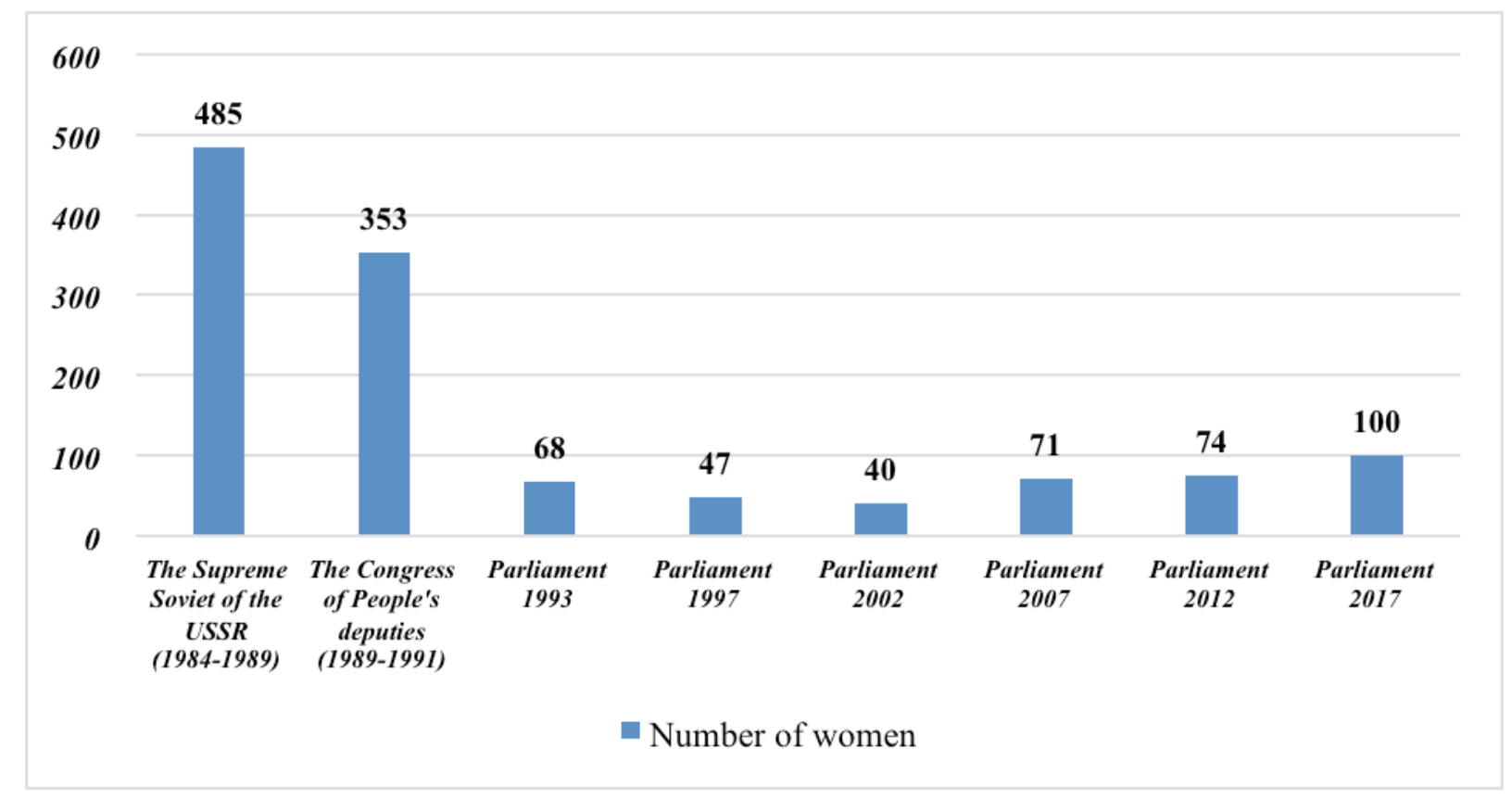

Annex 1. Number of women in the highest legislative bodies since 1984

December 25, 1991 changed everything. From that day Russia became an independent state and was recognized by the international community as the successor state of the USSR. The changes also affected the authorities. The Supreme Council was replaced by a bicameral Federal Assembly consisting of the State Duma and the Federation Council.

The first parliamentary elections were held on the same day -12.12 .1993 . Only 9 women were elected to the Federation Council, the upper house of the Federal Assembly. They accounted for $5 \%$ of the total number of deputies -171 . In the Duma, the situation was better: out of 450 deputies, 60 were female $-13.5 \%$.

An important achievement of 1993 in the area of gender policy was the inclusion of a women's political party in the lower house of Parliament. Hope for the transition to a "liberal" democracy contributed to the formation of the movement "Women of Russia" in 1993. In the elections of deputies to the state Duma of the 1st convocation "Women of Russia" scored 8.13\% of the vote and took fourth place. This result enabled them to obtain 23 mandates.

However, in 1995 the political activity of the population and women in particular decreased. During the period of political demobilization, many women's organizations were either marginalized or institutionalized by the government through their integration into other organizations. It exactly happened with the "Women of Russia". In the autumn of 1995, the number was reduced to 20. In the next parliamentary elections (December 1995) "Women of Russia" received $4.61 \%$ of the vote and took 5 th place without breaking the $5 \%$ barrier.

In 1996, there was a split of the party, one part of which "Lakhova's Women" created their own all-Russian socio-political movement of Russian women, and the other part of "Fedulova's Women" became the part of the political organization of Y. Luzhkov "Fatherland". In the 1999 parliamentary elections, electoral support for the "Women of Russia" was halved: they received only $2.04 \%$ of the votes. 
Another decrease in the number of women-deputies was observed in 1995. At this stage, the Federation Council was being reformed. In December 1995, a new Federal law was adopted, according to which "the head of the legislative (representative) and the head of the executive bodies of state power" are included in the upper house of Parliament "by the position" (Article 1 the Federal law of December 5, 1995, No. 192-FZ). Such changes have resulted in a record low number of women in the legislature - 0.5\%. In 1995-1996, only one woman represented one of the constituent entities - the Republic of Karelia. The Duma consisted of 47 female representatives $10.5 \%$.

After the 1995 elections, many women began to gain popularity regardless of party affiliation. E. Pamfilova from the "Republican party of the Russian Federation," the head of the Socialist workers' party L. Vartazarova and the leader of the "Democratic Union" V. Novodvorskaya have established themselves as influential politicians. E. Pamfilova received the status of "the lawyer on behalf of women" (Hays 2016).

In the following years, until 2007, there were minor fluctuations in the quantitative indicators in the chambers of the Federal Assembly [Annex 2]. The role of women in Russian politics increased dramatically in 2007. Thus, the state Duma of the fifth convocation consisted of 63 women, which accounted for $14 \%$ of the total number of deputies. It is important to note that this figure has almost doubled. There is also an increase in the number of female representatives in the Federation Council, from 6 to 8, with a decrease in the total number of representatives in the upper house of the Federal Assembly (178 and 169 respectively).

Currently, there is a record number of women in the legislative branch in Russian history. Nowadays 71 women are the members of the VII state Duma, which is the largest number in the history of its existence. The situation in the Federation Council is similar: 29 women is a record number. Despite the increasing trend in the number of female representatives, gender asymmetry remains a characteristic feature of the Supreme legislative power.

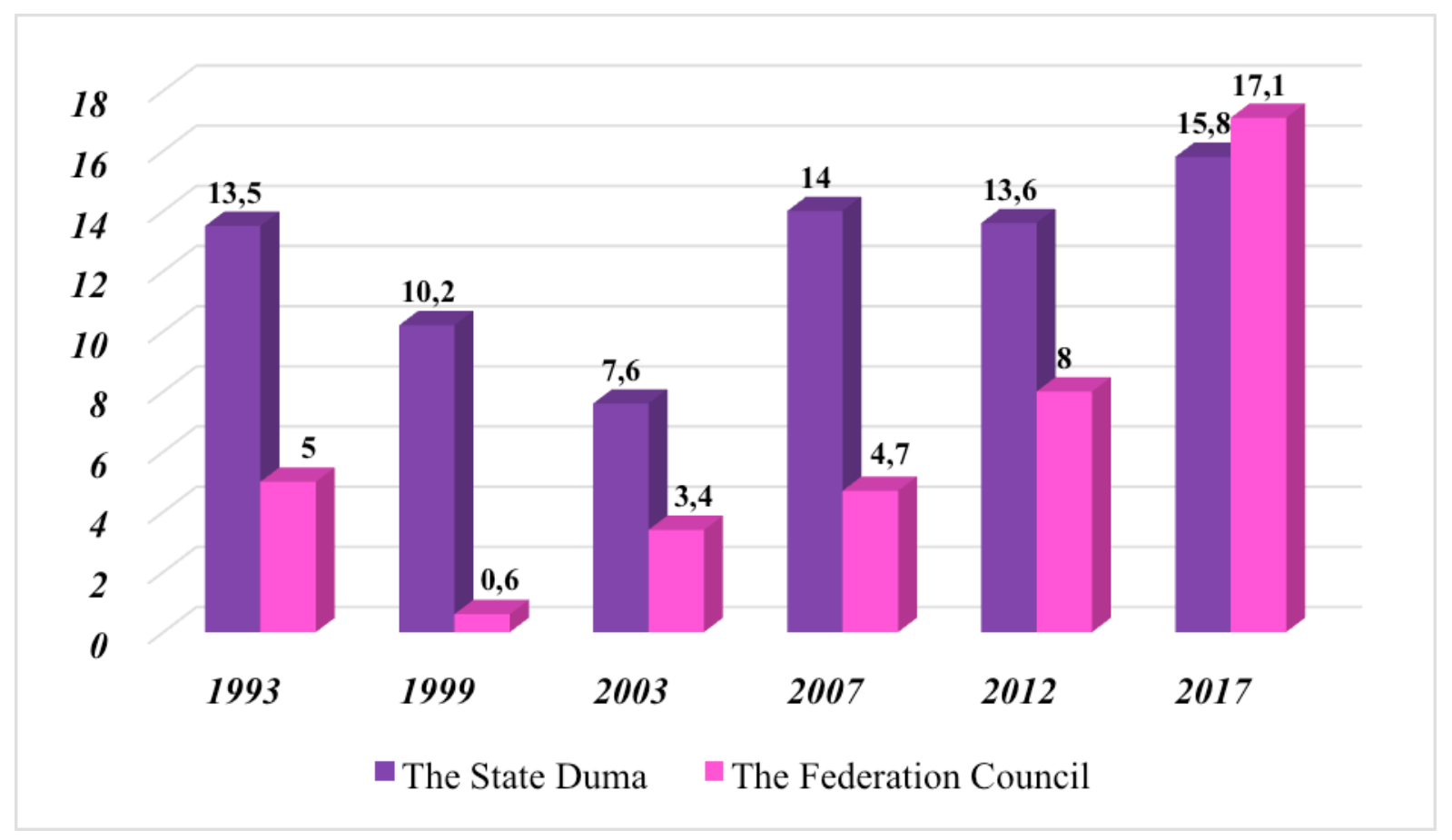

Annex 2. Share of women in the Russian Parliament (\%)

Therefore, it can be noted that the Russian example clearly fits into the theoretical features of formal political representation. Firstly, this type of representation does not necessarily lead to a significant number of women in political positions. As can be seen, Russian women remain largely unrepresented 
in political decision-making positions. This means that formal political equality is not sufficient to respect the principle of gender equality in politics. Secondly, the combination of historical factors and the elimination of gender quotas has played a crucial role in establishing formal women's political representation. However, the greatest research interest is the reasons why the gender policy in Russia stopped in development, and without moving to the next stage of gender representation - the descriptive one.

\section{Transition to descriptive representation: from theory to possibility}

Descriptive representation is expressed in a clear correspondence between political representatives and the electorate. That is, if women make up half of the country's population, they must also make up half of the executive and legislative branches (Haerpfer 2009, 268). The difference between formal and descriptive political representation is obvious: formal representation is only a profanation of gender equality, an opportunity to formally hide gender imbalance in the political sphere. By contrast, the descriptive representation is a real action to combat and possibly eliminate gender inequality.

Currently, the problem of gender imbalance in the Russian political arena continues to be relevant.

There is a gradual departure from the implementation of the principle of gender equality, especially in the field of public administration. Women, as a rule, contribute to the development of solutions, but not directly involved in it. Due to this the proportion of female "professionals" involved in the preparation of information, documentation, accounting and service, is $88 \%$. In this area, there are only 1 male out of 7 women.

Among the leaders (representatives) of the authorities and management at all levels, women are significantly less represented: the number of men is 1.5 times more than women. In the highest legislative body - the Federal Assembly - the gender imbalance is even greater: the number of male deputies exceeds the number of female parliamentarians by 5.2 times (Table 1).

Table 1. Distribution of employed men and women by areas in the legislature for 2017

\begin{tabular}{|c|c|c|c|c|}
\hline & Men (ths.) & Women (ths.) & Men (\%) & Women (\%) \\
\hline Legislature & 5000 & 7400 & 40,3 & 59,7 \\
\hline The Federal Assembly & 520 & 100 & 83,2 & 16,2 \\
\hline $\begin{array}{c}\text { Heads of authorities and } \\
\text { management at all levels }\end{array}$ & 10500 & 6800 & 62 & 38 \\
\hline Employees - "specialists" & 700 & 5200 & 12 & 88 \\
\hline
\end{tabular}

The introduction of women into political decision-making involves a number of social (consequences):

1. unequal distribution of power;

2. the lack of a clear mechanism to ensure equality between the sexes.

Thus, it can be concluded that there is no actual gender imbalance in the Russian political arena. Factually, women make up the quantitative majority of those employed in political structures. However, the "quality" of such representation is highly questionable: occupying only the lower echelons of power, women are virtually not involved in political decision-making. Such a provision cannot a priori correspond to descriptive political representation.

Another reason for the impossibility of moving to descriptive representation is the problem of male dominance in the political arena. There is an opinion that some high-ranking male politicians only "let in" female politicians who do not have their own opinion, look good and are essentially puppets (Kiryukhina 2013).

The most undervalued reason for the presence of formal female representation is the noninvolvement of gender issues within the political parties of Russia. The small number of women in decision-making positions in the legislative branch is linked to the low level of women's representation in the structures of parliamentary parties (Table 2). After the elections to the state Duma of the Federal Assembly of the VII convocation, held on September 18, 2016, the share of 
women in any parliamentary party does not reach $20 \%$. In half of the parties of the state Duma, the representation of women is less than $10 \%$.

Table 2. Representation of men and women in parliamentary parties of the Russian Federation

\begin{tabular}{|l|c|c|c|c|}
\hline & Overall number & Men & Women & $\begin{array}{c}\text { Proportion of } \\
\text { women (\%) }\end{array}$ \\
\hline $\begin{array}{l}\text { The State Duma } \quad 7^{\text {th }} \\
\text { convocation) }\end{array}$ & 450 & 379 & 71 & 15,8 \\
\hline United Russia & 343 & 280 & 63 & 18 \\
\hline Communist Party of Russia & 42 & 39 & 3 & 7 \\
\hline $\begin{array}{l}\text { Liberal Democratic Party of } \\
\text { Russia }\end{array}$ & 39 & 37 & 2 & 5 \\
\hline Just Russia & 23 & 20 & 3 & 13 \\
\hline Not included in the faction & 2 & 2 & 0 & 0 \\
\hline
\end{tabular}

The gender imbalance in parliamentary party structures is due to the absence of gender issues in their political programs. Through qualitative content analysis, the relationship between gender-articulated appeals in the political programs of parliamentary parties and the number of women in parliament was revealed. The choice of semantics was due to the method of feminist discourse analysis by C. Bacchi (Bacchi 1999, 56). The author argues that the problem of gender asymmetry in power can be demonstrated by addressing a number of specific issues, like discrimination, sexual harassment, access to education, child care, etc. The problem of gender inequality and imbalance of power has never been considered by the Russian parties elected to the supreme legislative body [Table 3].

Table 3. Content analysis of the programs of the Russian parliamentary parties for the presence of gender-articulated issues

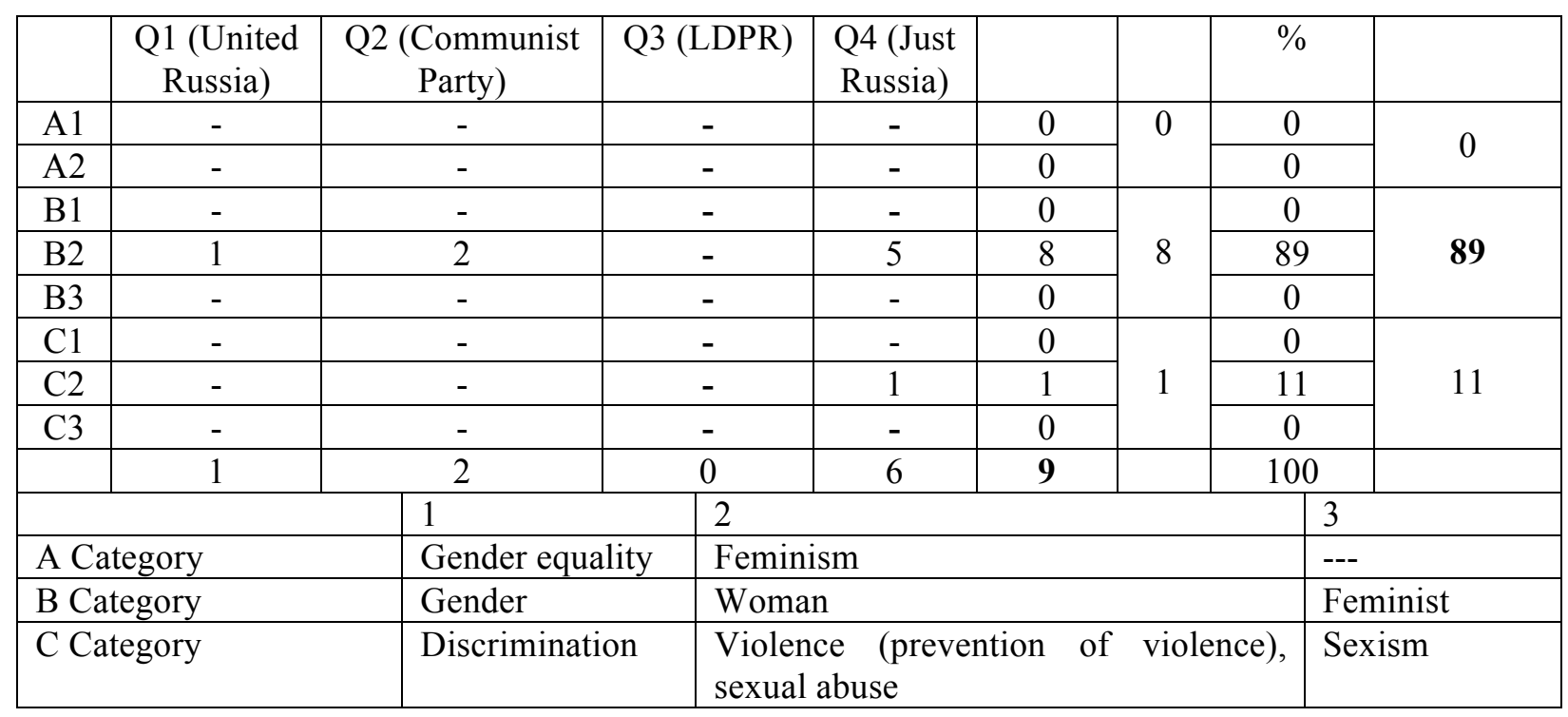

The election program of United Russia party in the last elections of deputies contains a female theme only in the form of "motherhood and childhood" protection. In this document, women are considered as mothers only (United Russia election program 2016, 64-65). The importance of care for pregnant women is emphasized: the program includes measures to improve the health care during pregnancy (Ibid).

It is important to note that even in the early twentieth century, Russian political parties did not reduce the "women's issue" only to the protection of maternal functions. They demanded that women's civil and political rights be fully respected (Russian political parties 2001, 28, 58). 
The Communist Party's program proposes “improving political work in ... women's organizations" in order to increase its political influence on social processes (CPRF program 2016). Russian communists in their political program do not raise the issues of motherhood and childhood.

The Liberal Democratic Party completely releases gender issues in its program, thus referring to parties that do not have gender-articulated appeals to voters.

The smallest party of the State Duma - Just Russia reveals the female question more fully, as compare with other parties. The party program pays great attention to the protection of women's labor rights. Fair Russians advocate for the creation of "the conditions under which women and people with family responsibilities can successfully combine work and education of children" (Just Russia program 2016, 26). Also, the political program of Just Russia is the only one that raises the issues of violence against women: "Proper attention should be paid to the prevention and investigation of acts of violence against women and punishment for them" (Ibid, 27).

Consequently, assessing party programs from the gender perspective, it should be noted that there is a close relationship between the numerical indicators of women in the legislature and the mainstreaming of gender issues in the main documents of the party. The LDPR, which is not putting their primary focus on gender issues, has the lowest percentage of female representation in the state Duma. United and Just Russia, mentioning only the "traditional" role of women, are gradually integrating women into the political process.

It can be assumed that political parties should ensure equal opportunities for women and men to develop the skills necessary for successful politicians. The main means of achieving this goal is to provide equal opportunities for both sexes to hold positions of responsibility at the party level and, as a consequence, in Parliament.

A large number of women in the civil service are accounted for by "specialists" and "support specialists" in various organizational and information matters. The structure of power must also be balanced: women must have a direct impact on different issues. Thereby, the problem of women's representation in politics is not their number in the state authorities, but the fact that they do not occupy any leading positions.

The formal nature of the involvement of women in politics is also confirmed by the statement that "female representatives are involved in Russian politics to meet the needs of the regime" (Johnson 2016). In times of crisis and change, women come to power to demonstrate democratic elections and fight corruption. According to Johnson, women act as "political cleaners", whose role is to cleanse politics of corruption (Ibid).

The low level of women's representation is also linked to the lack of prominent political parties supporting women's rights in the Russian legislature. "The Women of Russia" party, which emerged after the collapse of the USSR, "is no longer a force in Russian politics" and has not changed its political platform in ten years (Bukina 2015, 53).

\section{Conclusion}

To sum up, from the point of view of gender equality, the modern democratic society in Russia is formal, as there is only a formal commitment to the principles of gender equality. The combination of the above-mentioned reasons shows that neither the state nor the political parties are interested in promoting the principles of gender equality. All actions that take place in one way or another in the field of gender policy are done only when it is vital to demonstrate the development of democracy. Gender policy in Russia is not considered and implemented as part of democratic development. The political elite argues that the full implementation of the gender equality policy is impossible due to the prevailing social perceptions of the role of women. However, can a society be considered democratic if women are involved in politics only formally because it is some urgent necessity? In view of the facts mentioned the answer is obvious - no, because "society cannot be considered democratic if women play only a passive role in politics (as voters), do not participate in the government, do not occupy leadership positions...” (Lahova 1996). 
Nowadays the role of gender issues in Russia's democratization is the myth rather than the reality. However, in order to involve and further develop gender issues in the democratic development of Russia, it is essential to make a number of changes in the following areas:

I. Practical implementation of gender equality policy. Actions and activities to involve women should not only be carried out to improve statistical indicators and in times of crisis for the country. The process of achieving gender equality must be gradual and continuous.

II. Introduction of a party and / or parliamentary system of gender quotas. This system is one of the mechanisms for improving the gender balance in politics. A consequence of the lack of a functioning quota system in Russia is the low level of women's representation in the legislature, which limits overcoming the gender imbalance in the Parliament.

III. Increase in the number of gender-articulated appeals to voters by parliamentary parties. The programs of the parliamentary parties of Russia practically do not contain gender issues. This affects the formation of gender asymmetry in political parties and, therefore, in the whole political sphere.

IV. Respect for the principle of gender equality by political institutions. Structures interested in establishing and maintaining a high level of male and female political representation have a more gender-balanced environment in the public administration. The further development of gender equality policy depends directly on the activity of political institutions in its implementation. All of the above changes are likely to have a positive impact on the current gender situation in Russia and, in the future, on the democratic processes within the country.

\section{References}

Aivazova S. 2017. “Gendernyi' diskurs v pole konservativnoi politiki” (Gender discourse in the field of conservative politics). Zhenshchina $v$ politike (4): 3-13.

Bacchi C. 1996. "The Politics of Affirmative Action: 'Women', Equality and Category Politics.” SAGE: 108.

Bukina A. 2015. "Osobennosti programmnih ustanovok konservativnih partii sovremennoi Rossii” (Features of program installations of conservative parties of modern Russia). Pravo I sovremennie gosudarstva (4): 47-54.

Christian Haerpfer, Patrick Bernhagen, Ronald F Inglehart, and Christian Welzel. 2009. Democratization. Oxford University Press Canada: 708.

Election program of the "United Russia" in the elections of deputies of the State Duma (7th convocation). 2016. Accessed February 20, 2019. http://er.ru/party/program/.

Full collection of platforms of all Russian political parties. M.: State public historical library of Russia. $2001: 132$

Hays J. 2016. Women in Russia. Accessed February 20, 2019. http://factsanddetails.com/russia/People_and_Life/sub 9 2d/entry-5012.html.

Kiryukhina Y. 2013. Gender gap still wide in Russian politics. Accessed February $20,2019$. https://www.rbth.com/politics/2013/09/11/gender_gap_still_wide_in_russian_politics_29719.html.

Lahova E. 1996. Rol'zhenshchin $v$ democratizacii rossiskogo obschestva $(\bar{T}$ The role of women in the democratization of Russian society). Zhenshhchini v politike, politika dlya zhenshchin.

Loshakova U. 2013. "Regionalnye osobennosti gendernogo neravenstva" (Regional characteristics of gender inequality). SOCIS (5): 134-137.

Party program of the "Just Russia". 2016. Accessed February 20, 2019. http://www.spravedlivo.ru/5_76349.html.

Party program of the Communist Party of Russian Federation. 2016. Accessed February $20,2019$. https://kprf.ru/party/program.

Party program of the Liberal Democratic Party of Russia. 2016. Accessed February $20,2019$. https://ldpr.ru/party/Program_LDPR/.

The Federal law "On the order of formation of Federation Council of Federal Assembly of the Russian Federation" of 05.12.1995 No. 192-FZ. 